\title{
Effect of ultrasound pretreatment on the antioxidant capacity and antihypertensive activity of bioactive peptides obtained from the protein hydrolysates of Erythrina edulis
}

\author{
Carlos Martín Guerra-Almonacid ${ }^{1}$, Juan Gabriel Torruco-Uco ${ }^{2 *}$, Walter Murillo-Arango', \\ Jonh Jairo Méndez-Arteaga ${ }^{1}$, Jesús Rodríguez-Miranda ${ }^{2 *}$
}

${ }^{1}$ Departamento de Química, Grupo de Investigación de Productos Naturales, Facultad de Ciencias. Universidad del Tolima. Ibagué, Colombia, ${ }^{2}$ Tecnológico Nacional de México/Instituto Tecnológico de Tuxtepec, Av. Dr. Victor Bravo Ahuja S/N., Col. 5 de Mayo, Tuxtepec, Oaxaca, C.P. 68350 , México

\section{A B S TR A C T}

\begin{abstract}
The aim of this research was to evaluate the effect of ultrasound pretreatment on enzymatic hydrolysis with Flavourzyme ${ }^{\circ}$ and Alcalase enzymes and the ACE-inhibitory activity and the antioxidant capacity of protein hydrolysates of Erythrina edulis. A protein concentration of $78.8 \%$ was obtained after sonicating the protein solutions $(10 \%, \mathrm{w} / \mathrm{v})$ for $10 \mathrm{~min}$ at $80 \mathrm{kHz}$ and $100 \%$ amplitude. The ultrasonic pretreatment (UP) increased the degree of hydrolysis $(47.7 \%)$ up to $70 \mathrm{~min}$, the $/ C_{50}$ values in both samples [with (UP) and without pretreatment (WP)] were $100 \mu \mathrm{g} / \mathrm{mL}$, and the UP samples presented the highest percentage of inhibition at $57.3 \%$. The UP hydrolysates showed the highest $(p<0.05)$ antioxidant $\left(\mathrm{ABTS}{ }^{*}\right)$ and radical $\left(\mathrm{DPPH}^{*}\right)$ - scavenging activities, with $/ C_{50}$ values ranging from 64.52 to $77.62 \mu \mathrm{g} / \mathrm{mL}$ and from 151.13 to $173.22 \mu \mathrm{g} / \mathrm{mL}$, respectively. In SDS-PAGE, the hydrolysates UP exhibited low molecular weight bands $(8-20 \mathrm{kDa})$. The results of both, antioxidants and antihypertensive activities obtained in vitro, showed a higher percentage of activity for the peptides obtained after pretreatment with ultrasound than for those obtained without the use of ultrasound prior to enzymatic hydrolysis.
\end{abstract}

Keywords: Ultrasound; Antioxidant; Antihypertensive; Bioactive peptides; Hydrolysys

\section{INTRODUCTION}

Erythrina edulis is one of the 115 species of the Erythrina genus found in the world and is also known as pajuro, poroto, water plant or native chachafruto of Latin America. It is a legume that has an average height of between 10 and 15 metres, and its leaves have an intense dark green colour with small thorns on the midrib of the posterior face. It also has very bright red crimson cores arranged in an elongated cluster that become elongated and slightly rounded pods with a light green and bright colour, which contain several grains or seeds commonly used for animal nutrition and human food due to their high protein content (16 to 25\%) (Cárdenas, 2012; Arango-et al., Guerrero, 2012; Morillo et al., 2013). Currently, there is great interest in protein hydrolysates due to their diverse applications (Guerra et al., 2017). Enzymatic hydrolysis improves the chemical, functional and nutritional properties of protein hydrolysates (Torruco-Uco et al., 2009). For this reason, research has been carried out on legumes such as Phaseolus lunatus, Phaseolus vulgaris and Glycine max (Torruco-Uco et al., 2009; Guerra et al., 2017; Hanafi et al., 2018), obtaining bioactive peptides (Torruco-Uco et al., 2009; Udenigwe and Aluko 2012). Intiquilla et al. (2016), evaluated the ability of microbial proteases $\left(\right.$ Neutrase $^{\circledR}$, Flavourzyme ${ }^{\circledR}$ and Alcalase ${ }^{\circledR}$ ) to produce antioxidant peptides from the Erythrina edulis protein. Found a degree of hydrolysis (DH) at 120 min of $40 \%$ with Neutrase ${ }^{\circledR}, 28.5 \%$ with Alcalase ${ }^{\circledR}$ and $42.3 \%$ with Flavourzyme ${ }^{\circledR}$. Intiquilla et al. (2018) evaluated the potential of the Erythrina edulis protein as a source of antioxidant peptides, hydrolyzed with

\section{*Corresponding authors:}

Jesús Rodríguez-Miranda and Juan Gabriel Torruco-Uco, Tecnológico Nacional de México/Instituto Tecnológico de Tuxtepec, Av. Dr. Victor Bravo Ahuja S/N., Col. 5 de Mayo, Tuxtepec, Oaxaca, C.P. 68350, México. E-mail: jesrodmir@gmail.com, jtorruco79@outook.com 
alcalase $^{\circledR}(120 \mathrm{~min})$. Reaching a final value of the DH of $37.03 \pm 0.88 \%$, showed potent ABTS* and peroxyl radical scavenging activity with TEAC and ORAC values of $1.37 \pm 0.09 \mu \mathrm{mol} \mathrm{TE} \mathrm{mg}^{-1}$ peptide and $2.83 \pm 0.07 \mu \mathrm{mol}$ TE $\mathrm{mg}^{-1}$ peptide, respectively. In addition to identifying ten new peptides with antioxidant effects in vitro from the protein hydrolyzate Erythrina edulis with Alcalase ${ }^{\circledR}$ and which therefore contains a complex mixture of peptides. However, alternatives that increase these activities have been sought. The sequential hydrolysis increases the degree of protein hydrolysis as shown by Chirinos et al. (2018). Hydrolysates were obtained via enzymatic hydrolysis using food grade enzymes. In this sense, the application of ultrasound is able to increase the yields of extraction of polyphenols and $\% \mathrm{DH}$ in concentrates and protein isolates, helping to improve the antioxidant capacity of the extracts (Wang et al., 2015; Zhang et al., 2015; Li et al., 2018, Xiong et al., 2018), this is achieved through the chemical, mechanical and physical effects of acoustic cavitation (Chen et al., 2011). The treatment with ultrasound modifies the conformation of the protein (Chen et al., 2011; Jia et al., 2010: Zhang et al., 2015; Li et al., 2018; Xiong et al., 2018). Consequently, a combination of pretreatment with ultrasound and sequential enzymatic hydrolysis could be a promising way to modify the functionality of globular proteins. Therefore, the aim of this research was to evaluate the effect of ultrasound pretreatment on enzymatic hydrolysis of the enzymes, Flavourzyme ${ }^{\circledR}$ and Alcalase ${ }^{\circledR}$, and the ACE inhibitory activity and the antioxidant capacity of the protein hydrolysates of Erythrina edulis.

\section{MATERIALS AND METHODS}

\section{Materials}

Erythrina edulis was collected in the municipality of Rioblanco Tolima, Colombia. The enzymes, Flavourzyme ${ }^{\circledR}$ and Alcalase ${ }^{\circledR}$,were purchased from Sigma-Aldrich (Sigma Chemical Co., St. Louis, MO, USA). All other reagents used in this study were analytical grade chemicals. The chemical composition of the flour was 18.5, 3.3, 0.9, 1.5, 2.6 and $73.2 \%$ of protein, moisture, fat, ash, fibre and carbohydrates contents. The samples were placed in vacuum-sealed polyethylene bags and stored at $4 \pm 0.5^{\circ} \mathrm{C}$ until later use.

\section{Preparation of Erythrina edulis flour}

The seeds of Erythrina edulis were cleaned by hand and subsequently ground in a mill (Thomas Wiley brand) and sieved, mesh No. $200(74 \mu \mathrm{m})$ (standard test sieve ASTM E-11 specification W.S. Tyler, USA). The flour was defatted with hexane in a Soxhlet system for at $50^{\circ} \mathrm{C}$ for $2 \mathrm{~h}$ (ED 115 Binder Oven, Germany) (Rodríguez-Miranda et al., 2012). The defatted flour was screened through a no. 100 (149 $\mu \mathrm{m})$ mesh (standard test sieve ASTM E-11 specification W.S. Tyler, USA).

Preparation of Erythrina edulis protein concentrate (PC) The PC was fractionated using an established method by Betancur-Anacona et al. (2004) with some modifications (Fig. 1). To raise the $\mathrm{pH}, 1 \mathrm{~N} \mathrm{NaOH}$ was added to the flour suspension to reach $\mathrm{pH} \mathrm{11}$, and the suspension was stirred for $75 \mathrm{~min}$ at $450 \mathrm{rpm}$. The suspension was then centrifuged (Hermle-Z32HK, Germany) at $4000 \times \mathrm{g}$ for $30 \mathrm{~min}$, and the supernatant was adjusted with $1 \mathrm{~N} \mathrm{HCl}$ to $\mathrm{pH} 4.2$, the isoelectric point (The obtained extracts were taken to different $\mathrm{pH}$ in a range of 3 to 6 using 1 $\mathrm{N} \mathrm{HCL}$, and the protein content of the supernatants and precipitates obtained in each sample was evaluated. The isoelectric point in the range in which the supernatant was lower and the precipitate higher protein content was stabilized), and filtered by a no. 100 mesh $(149 \mu \mathrm{m}$, standard test sieve ASTM E-11 specification W.S. Tyler, USA), again to steps 1 to three twice as shown in Fig. 1; after being centrifuged at $4000 \times \mathrm{g}$ for $30 \mathrm{~min}$, the precipitate was washed with distilled water 10 times; subsequently, the precipitate was freeze-dried. The protein content was determined by the micro-Kjeldahl method ( $\mathrm{N}$ x 6.25) (Rahmaninia et al., 2018). The PC obtained had a protein content of $78.8 \%$.

\section{Ultrasound pretreatment (UP)}

The PC dispersions $(10 \%, \mathrm{w} / \mathrm{v})$ were prepared in distilled water (Resendiz-Vazquez et al., 2017) and stirred in a vortex (Vortex-2 Genie, Model G-560, Scientific Industries, Inc., Bohemia, NY, 11716, USA) for $1 \mathrm{~min}$ at $\approx 20 \mathrm{rpm}$. An Elmasonic ultrasonic bath (Model P30 H, Elma Schmidbauer GmbH Gottlieb-Daimler-Str. 17 D-78224, Singen, Germany) with a volume of $1.9 \mathrm{~L}$ was used. The UP was performed with a frequency of $80 \mathrm{kHz}$ and an amplitude of $100 \%$ for 10 min. After the UP, the samples were freeze-dried and placed in vacuum-sealed polyethylene bags and stored at $4 \pm 0.5^{\circ} \mathrm{C}$ until later use.

\section{Enzymatic hydrolysis}

The method described by Adler-Nissen, (1986) with some modifications (Pedroche et al., 2002; and Guerra et al., 2017) was used for the hydrolysis of the PC.

\section{ACE-inhibitory activity}

The ACE-inhibitory activity was measured by the method of Cushman and Cheung (1971) with slight modifications, as described in a previous publication (Muguerza et al., 2006).

\section{Effects of ultrasound on antioxidant activities ABTS* inhibition activity}

The methodology described by Kuskoski et al. (2004) was followed. 


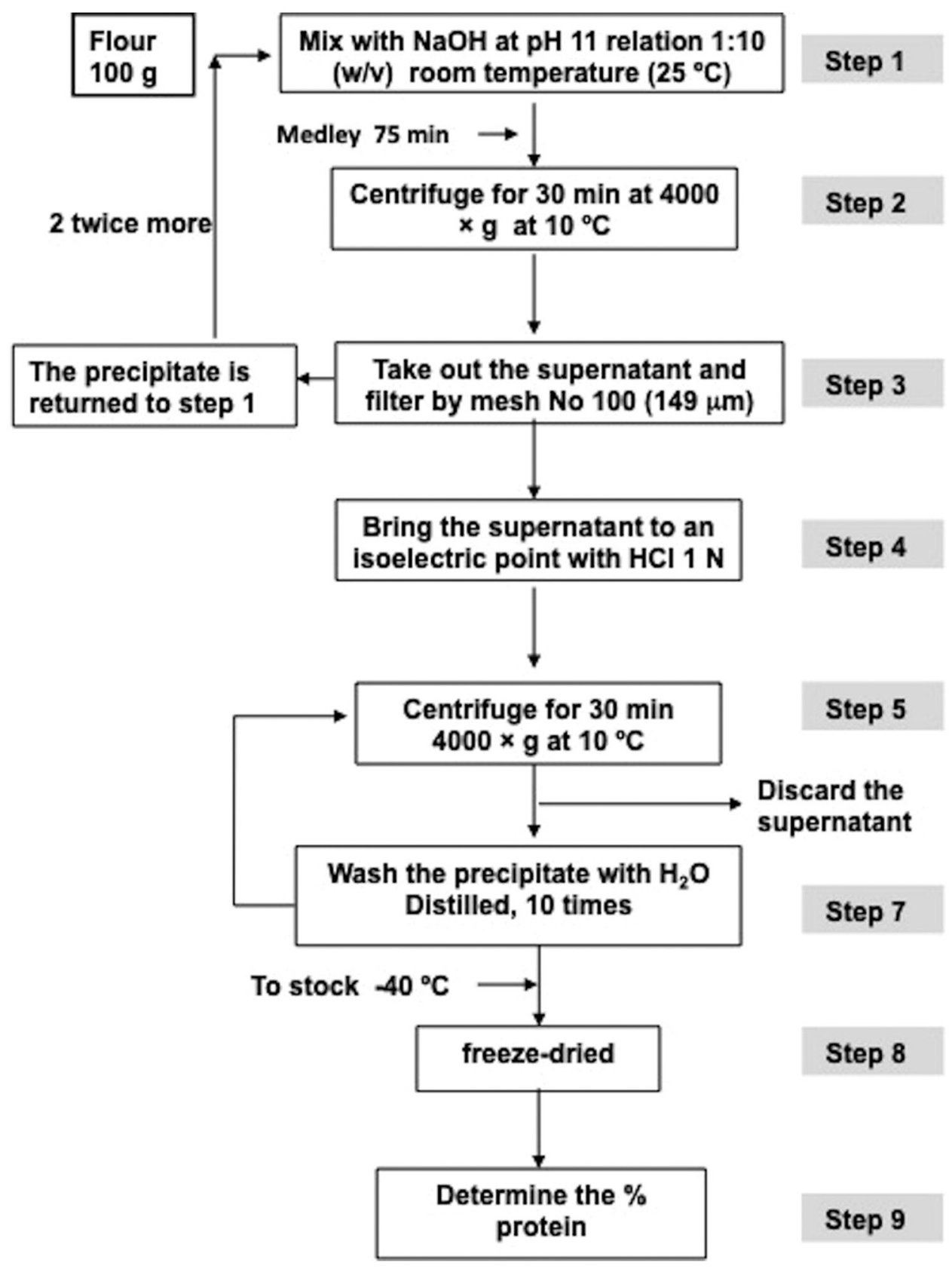

Fig 1. Schematic diagram of experimental obtaining protein concentrate.

$D P P H^{*}$ inhibition activity

The methodology described by Braca et al. (2002) was followed with slight modification.

\section{SDS-PAGE Electrophoresis}

Sodium dodecyl sulphate polyacrylamide gel electrophoresis (SDS-PAGE) of PC, UP and WP was performed following the method of Sambrook et al. (1989) using 12\% separating gel and $5 \%$ stacking gel. The samples were dissolved in sample buffer $(0.001 \mathrm{~g}$ in 200 microliters of reducing SDS loading buffer containing $50 \mathrm{mM}$ tris- $\mathrm{HCl} \mathrm{pH}=6.8$, $100 \mathrm{mM}$ dithiothreitol, $10 \%$ glycerin, $2 \%$ SDS, and $0.1 \%$ bromophenol blue). After heating samples for $3 \mathrm{~min}$ at $90{ }^{\circ} \mathrm{C}$ and cooling to room temperature $\left(25^{\circ} \mathrm{C}\right), 10 \mu \mathrm{g}$ of protein was loaded onto gels, and run in OmniPage Mini Vertical Systems (Cleaver Scientific, Warwickshire, UK) using Tris-glycine-SDS buffer as the running buffer. The conditions were set at $200 \mathrm{~V}$ constant, and the gels were run for $45 \mathrm{~min}$. Sigma MarkerTM (ColorBurst Electrophoresis Marker - C1992 -Sigma Chemical), was used as molecular weight marker. After electrophoresis, the gels were stained with Coomassie Blue for $60 \mathrm{~min}$, destained with a $10 \%$ acetic acid- $10 \%$ methanol solution for $12 \mathrm{~h}$, and photographed using a digital camera. 


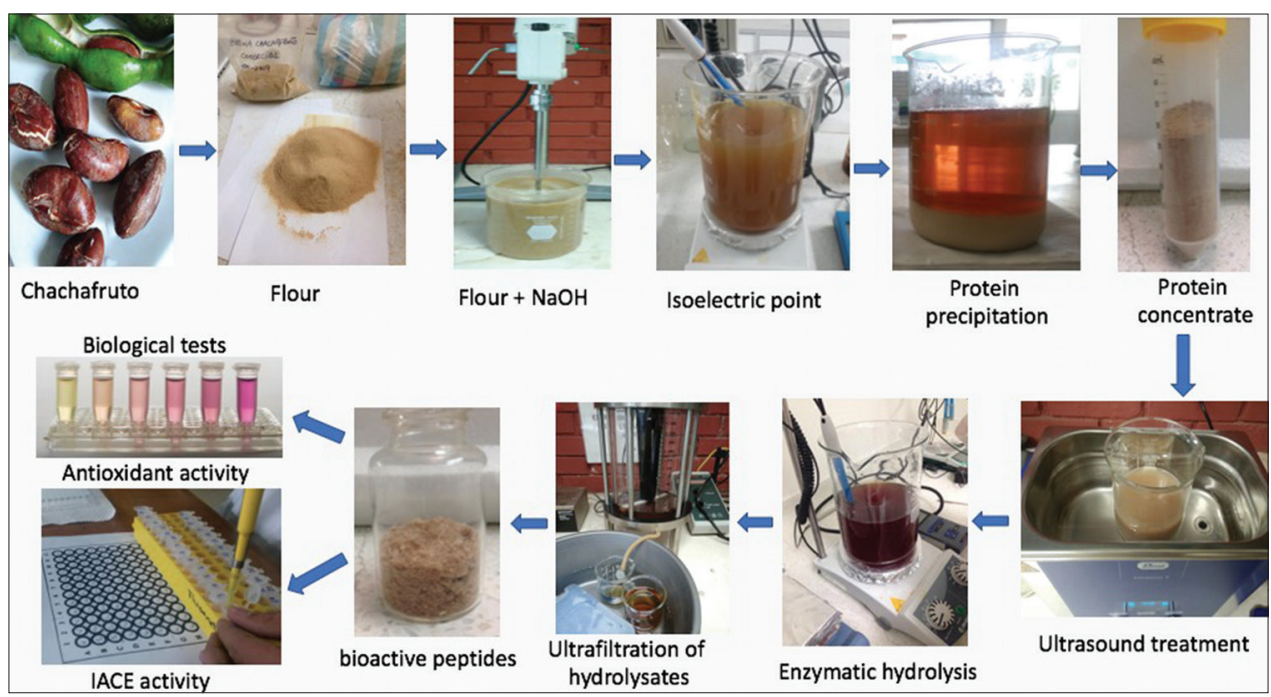

Fig 2. General diagram of the ultrasonic pretreatment and enzymatic hydrolysis of the Erythrina edulis protein concentrate.

\section{Gel filtration chromatography}

Gel filtration chromatography profile of hydrolysates (UP and WP) on Sephadex G-15 column $(1.8 \times 60 \mathrm{~cm})$ (Beijing RuiDaHengHui Science \& Technology Development co. Ltd, China). Separation was performed at a flow rate of $0.5 \mathrm{~mL} / \mathrm{min}$ with $20 \mathrm{mM}$ sodium acetate-acetic acid buffer solution ( $\mathrm{pH} 4.0)$ and collected at a fraction volume of $3 \mathrm{~mL}$. The absorbance of the samples was measured at $260 \mathrm{~nm}$.

\section{Statistical analysis}

The results were analysed using a one-way analysis of variance (ANOVA), and the differences between the means were determined by a least significant difference test (LSD) with a confidence level of 95\% using Statistica Version 8 software (StatSoft, Inc. 1984-2008, USA).

\section{RESULTS AND DISCUSSION}

\section{Effect of ultrasound pretreatment on enzymatic hydrolysis}

Fig. 3 shows the effect of the ultrasonic pretreatment on the degree of hydrolysis (DH) of the PC of Erythrina edulis. The percentage of DH of both samples with (UP) and without pretreatment (WP) ultrasound pretreatment showed the same tendency to increase with increasing hydrolysis time, showing significant differences $(p<0.05)$. However, at 60 and $70 \mathrm{~min}$, the WP samples were not significantly different ( $>>0.05$ ), with $37.2 \%$ being the highest $\% \mathrm{DH}$ for the WP samples. The samples the with the UP presented higher values $(p<0.05)$ at all times than those of the WP samples. The highest $\% \mathrm{DH}$ value of $47.7 \%$ was found for the UP samples at $70 \mathrm{~min}$ of hydrolysis; therefore, the use of the ultrasonic pretreatment increased by $10.2 \%$ with respect to the WP sample at $70 \mathrm{~min}$. This is because ultrasound

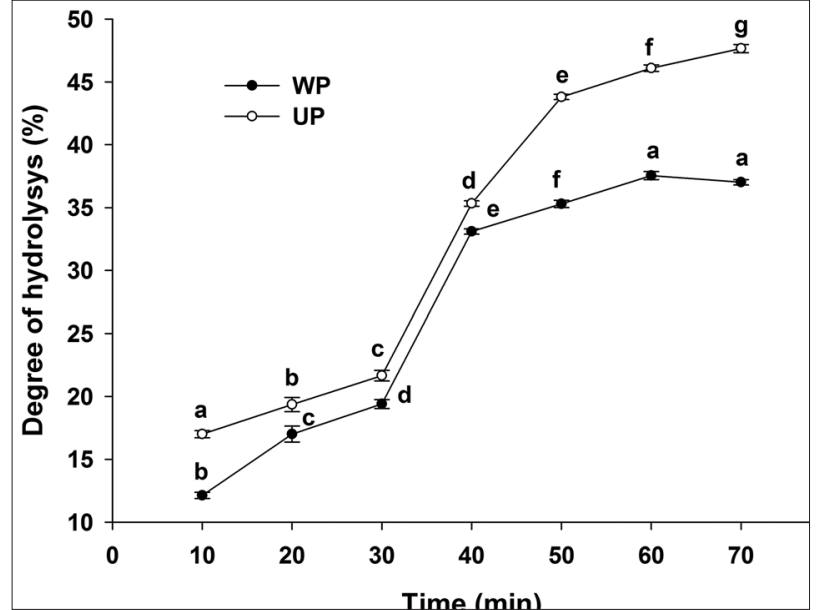

Fig 3. Effect of ultrasonic pretreatment on degree of hydrolysys of the protein concentrate $E$. edulis. The results are indicated as mean \pm standard deviation $(n=3)$. WP $=$ without pretreatment, UP $=$ ultrasonic pretreatment. Different letters indicate significant differences $(p<0.05)$.

produces a series of chemical and physical changes in the protein, such as mechanical effects, cavitation, heating effects, dynamic agitation, shear stress and turbulence (Wang et al., 2015; Zhang et al., 2017). These effects include breaking the covalent bonds, changing the protein structures and promoting the enzymatic hydrolysis process by increasing the combination of enzymes and proteins (Wang et al., 2015; Jia et al., 2010; Ding et al., 2018). The results suggest that the UP contributes to the breakdown of strong intermolecular interactions of the solute-matrix, including Van der Waals forces and hydrogen bonds (Ding et al., 2018). The $\% \mathrm{DH}$ (37.2 to $60 \mathrm{~min}$ ) found for samples without the ultrasound pretreatment was in the range of values reported by other authors in PC of Erythrina edulis, Intiquilla et al. (2016) report 43.3\% after 120 min using 
Flavourzyme $^{\circledR}$, while Intiqilla et al. (2018) reported 37.03\% in 120 min using Alcalase ${ }^{\circledR}$. Therefore, this research shows that with the sequential use of enzymes during hydrolysis, the hydrolysis time is significantly reduced to $50 \%$ to reach the same $\% \mathrm{DH}$. The value of $\mathrm{WP}(37.2 \%)$ was in the range of values reported for other legumes. Guerra et al. (2017) measured the protein concentration $(82 \%)$ of mung bean (Vigna Radiata) using the commercial enzymes, Alcalase ${ }^{\circledR}$, trypsin $^{\circledR}$ and Flavourzyme ${ }^{\circledR}$, and achieved \%DH values of $40.81,30.45$ and $37.45 \%$, respectively, after $60 \mathrm{~min}$ of hydrolysis. Torruco-uco et al. (2009) reported a DH value of $37.94 \%$ for the protein concentrate $(71.8 \%)$ of P. Lunatus after reacting with Alcalase ${ }^{\mathbb{P}}$ for $45 \mathrm{~min}$ and a value of $49.48 \%$ for the protein concentrate $(63.8 \%)$ of P. vulgaris after $30 \mathrm{~min}$ of reaction time. The $\% \mathrm{DH}$ found for the UP samples of this study is higher than that of oatisolated protein reported by Wang et al. (2015), which was $58.3 \%$; after 20 min of ultrasonic pretreatment at $750 \mathrm{~W}$ and $60 \mathrm{~min}$ of enzymolysis with Alcalase ${ }^{\circledR}$. The value of $\% \mathrm{DH}$ was $32.1 \%$. Ding et al. (2018) in protein concentrates of grape seeds hydrolyzed with Alcalase ${ }^{\circledR}$ for 90 min with pretreatment of dual ultrasonic $(20 / 35 \mathrm{kHz})$ for $20 \mathrm{~min}$, DH of $40-47 \%$. Zhang et al. (2017) treated pig skin collagen hydrolysates with Alcalase ${ }^{\circledR}$ after pretreatment with ultrasound $(25 \mathrm{kHz}$ at an ultrasonic power of $290 \mathrm{~W}$ for $40 \mathrm{~min}$ (pulse durations of $1 \mathrm{~s}$ on and $3 \mathrm{~s}$ off)) and alkali and achieved a $\% \mathrm{DH}$ value of $32 \%$ after $180 \mathrm{~min}$ of hydrolysis.

\section{Effect of ultrasound pretreatment on ACE-inhibitory activity}

Significant differences were found $(\phi<0.05)$ between the concentrations used in both treatments (UP and WP) Fig. 4. The concentration was $100 \mu \mathrm{g} / \mathrm{mL}$ when more than

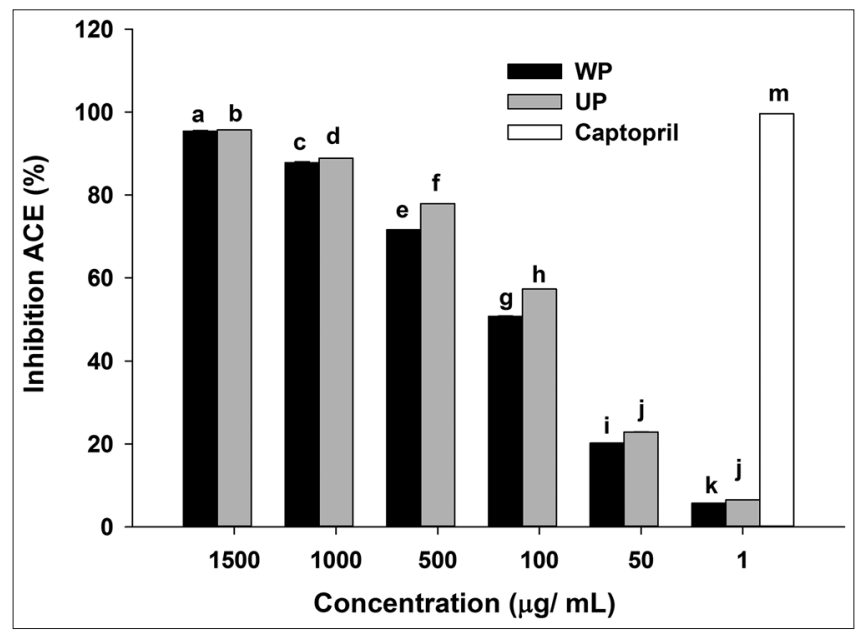

Fig 4. Effect of ultrasonic pretreatment on inhibition ACE (\%) of the protein concentrate $E$. edulis. The results are indicated as mean \pm standard deviation $(n=3)$. WP $=$ without pretreatment, $\mathrm{UP}=$ ultrasonic pretreatment. Different letters indicate significant differences $(p<0.05)$.
$50 \%$ inhibition was reached in both groups (UP and WP); however, the UP group presented higher \% inhibition (57.3\%) compared to the WP group (50.7\%). These differences are resulting in forces that are able to break the chains of protein molecules, thus improving proteolysis and the release of peptides, (Bosiljkov et al., 2011; Ren et al., 2014; Liu et al., 2018). This effect was also reported by Jia et al. (2010). Ren et al. (2014) reported that pretreatment with fixed-frequency ultrasound at $40 \mathrm{kHz}$ increased the ACE-inhibitory activity of zein hydrolysate by $97 \%$ compared to the control. The values of $I C_{50}$ found in this investigation are within the range $(56-1140 \mu \mathrm{g} / \mathrm{mL}$ ) reported for protein concentrates from other plant sources, such as Phaseolus lunatus, Phaseolus vulgaris, chickpea seed, green soybeans, cañihua and oats (Torruco-Uco et al., 2009; Hanafi et al., 2018; Chirinos et al., 2018; Gupta and Bhagyawant, 2018; Wang et al., 2015). Therefore, it can be concluded that the ultrasonic pretreatment effectively increased the ACE-inhibitory activity of hydrolysed peptides from Erythrina edulis protein. However, $I C_{50}$ values indicate the ability of the hydrolyzate to inhibit ACE and cannot be completely attributed to the degree of hydrolysis, but can be provided by the amino acid composition of the peptides present in the hydrolysates, which in turn depends on the activity proteolytic enzyme system used (Tsai et al., 2008; Chirinos et al., 2018) therefore further studies on the amino acid composition of the peptides obtained in this research need to be carried out.

\section{Effects of ultrasound on antioxidant activities ABTS* inhibition activity}

The ABTS* radical activity assay was analysed at different times of hydrolysis of the PCs to investigate more thoroughly the effect of UP on the antioxidant capacity of the obtained hydrolysates. The UP hydrolysates showed

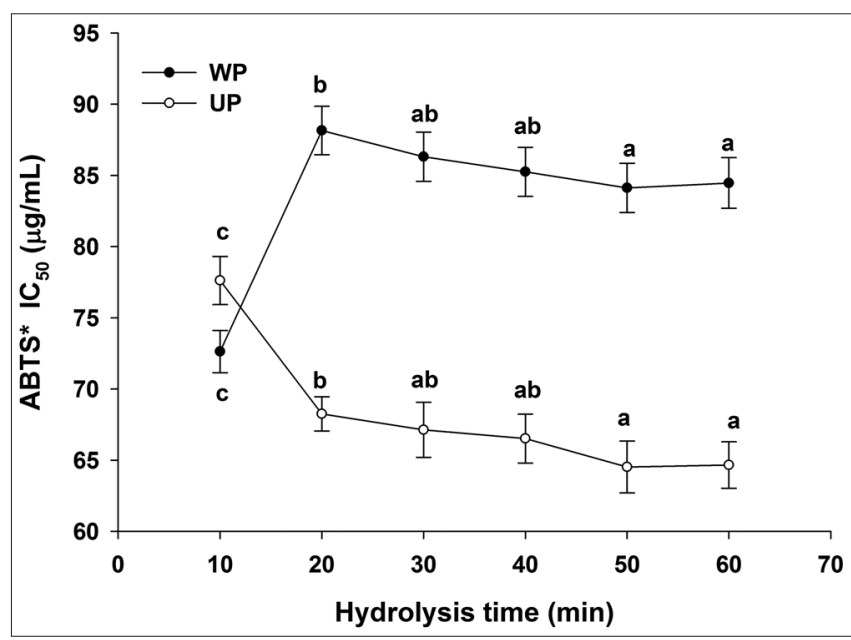

Fig 5. Effect of ultrasonic pretreatment on ABTS* $I C_{50}$ of the protein concentrate $E$. edulis. The results are indicated as mean \pm standard deviation $(n=3)$. WP $=$ without pretreatment, UP $=$ ultrasonic pretreatment. Different letters indicate significant differences $(p<0.05)$. 
the best $(p<0.05)$ antioxidant activity (ABTS*) with $I C_{50}$ values of 77.62 to $64.65 \mu \mathrm{g} / \mathrm{mL}$ (Fig. 5). However, no significant difference was found $(p>0.05)$ among samples hydrolysed for 30, 40, 50 and $60 \mathrm{~min}$, with an average value of $65.71 \mu \mathrm{g} / \mathrm{mL}$. The WP hydrolysates showed lower activity with $I C_{50}$ values of 72.62 to $84.14 \mu \mathrm{g} / \mathrm{mL}$. These results of the radical (ABTS*)-trapping activity of the UP hydrolysates indicate that these hydrolysates favoured the hydrolysis of peptides or substances that are electron donors and that can react with free radicals to yield more stable products and end the reaction in the radical chain (Torruco-Uco et al., 2009; Schaich et al., 2015; Intiquilla et al., 2019). The presence of tyrosine at the C-terminal extreme of peptide seems to be primary for the ABTS* radical scavenging activity of vegetable proteinsderived peptides (Babini et al., 2017), and according to Intiquilla et al. (2016) the essential amino acids present in greater proportion in the PC of Erythrina edulis, are Leu, Lys, Phe, Val and Tyr. This is in agreement with the results of Li et al. (2018) for quinoa protein isolates pre-treated with ultrasound, which showed greater radical-trapping activity than the control. The value of WP is lower than that reported by Guerra et al. (2017) in protein hydrolysates of mung bean with $\operatorname{Trypsin}^{\circledR}$ and Flavourzyme ${ }^{\circledR}$ with $I C_{50}$ values of 81.89 and $123.44 \mu \mathrm{g} / \mathrm{mL}$, respectively, as well as by low hydrolyzate with Alcalase ${ }^{\circledR} I C_{50}=81.89 \mu \mathrm{g} / \mathrm{mL}$.

\section{$D P P H^{*}$ inhibition activity}

Antioxidants can interact with free radicals and form stable species, which end oxidation (You et la., 2009). The free radical, $\mathrm{DPPH}^{*}$, has been widely used to evaluate reducing substances (Bae and Suh, 2007). Fig. 6 shows the effect of the ultrasonic pretreatment on the radical-trapping activity $\left(\mathrm{DPPH}^{*}\right)$ and the hydrolysis time of the PCs of Erythrina edulis. The antioxidant activities of both samples (UP and WP) tended to increase after the hydrolysis time had elapsed. Significantly high values $(p<0.05)$ of the trapping activity of $\mathrm{DPPH}^{*}$ radicals were found for the UP samples with $I C_{50}$ values of 151.13 to $173.22 \mu \mathrm{g} / \mathrm{mL}$ (Fig. 5). No significant difference was found $(p>0.05)$ among samples hydrolysed for 20, 30 and $40 \mathrm{~min}$ (average $152.3 \mu \mathrm{g} / \mathrm{mL}$ ) and between 50 and $60 \mathrm{~min}$ (average $148.1 \mu \mathrm{g} / \mathrm{mL}$ ). The WP samples showed lower activity with $I C_{50}$ values of 152.72 to $182.22 \mu \mathrm{g} / \mathrm{mL}$. The ultrasonic pretreatment helped that during the hydrolysis the fractions of proteins with great molecular weight were degraded in fractions of relatively small molecular weight with the capacity to donate electrons and that could react with free radicals to turn them into products more stable, thus ending chain reactions (Aderinola et al., 2019; Yang et al., 2008; 2011). The higher uptake capacity of DPPH radicals in UP may be due to the presence of greater amounts of hydrophobic residues compared to WP, since hydrophobicity could have improved the peptide interactions with DPPH molecules
(Sarmadi and Ismail, 2010, Jarotimi et al., 2018). Therefore, ultrasonication improves free radical-trapping activity, a finding that coincides with those reported by other authors, where the activity increased with the use of ultrasonication (Nadeem et al., 2018; Jiang et al., 2018; Ma et al., 2018).

\section{SDS-PAGE}

Fig. 7 shows the page SDS-page, the protein profile of hydrolysates (UP and WP) and PC. The SDS-PAGE profile of the samples showed significant difference between the samples. The UP sample exhibited five low molecular weight bands ranging from 8 to $20 \mathrm{kDa}$, based on the width and intensity of the band, compared to WP. According to Torruco-Uco et al. (2009), the presence of low molecular

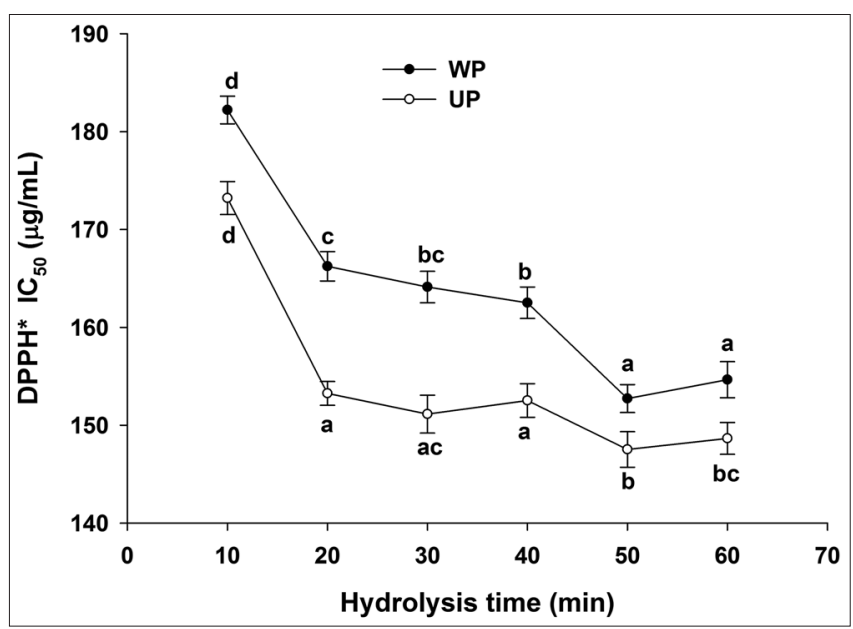

Fig 6. Effect of ultrasonic pretreatment on $\mathrm{DPPH}^{\star} I C_{50}$ of the protein concentrate $E$. edulis. The results are indicated as mean \pm standard deviation $(n=3)$. WP $=$ without pretreatment, UP = ultrasonic pretreatment. Different letters indicate significant differences $(p<0.05)$.

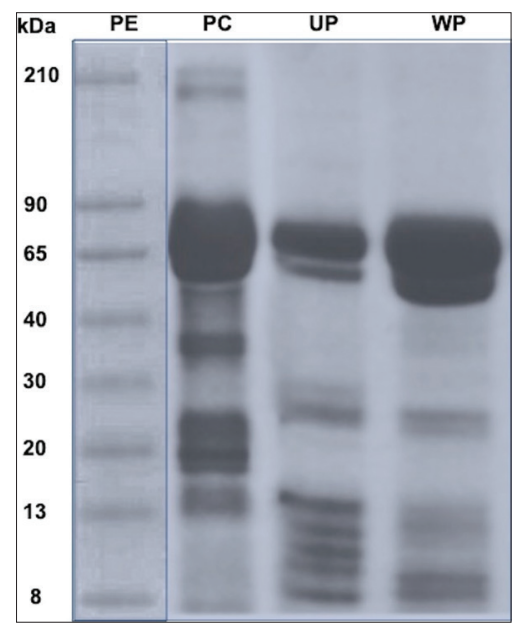

Fig 7. SDS-PAGE electrophoretic profiles of $\mathrm{PE}=$ molecular weight marker (ColorBurst Electrophoresis Marker - C1992 Sigma). $\mathrm{PC}=$ protein concentrate of $E$. edulis, UP $=$ hydrolyzed protein of $E$. edulis with ultrasonic pretreatment and hydrolysis time of $60 \mathrm{~min}$, $\mathrm{WP}=$ hydrolyzed protein of $E$. edulis without ultrasonic pretreatment and hydrolysis time of $60 \mathrm{~min}$. 


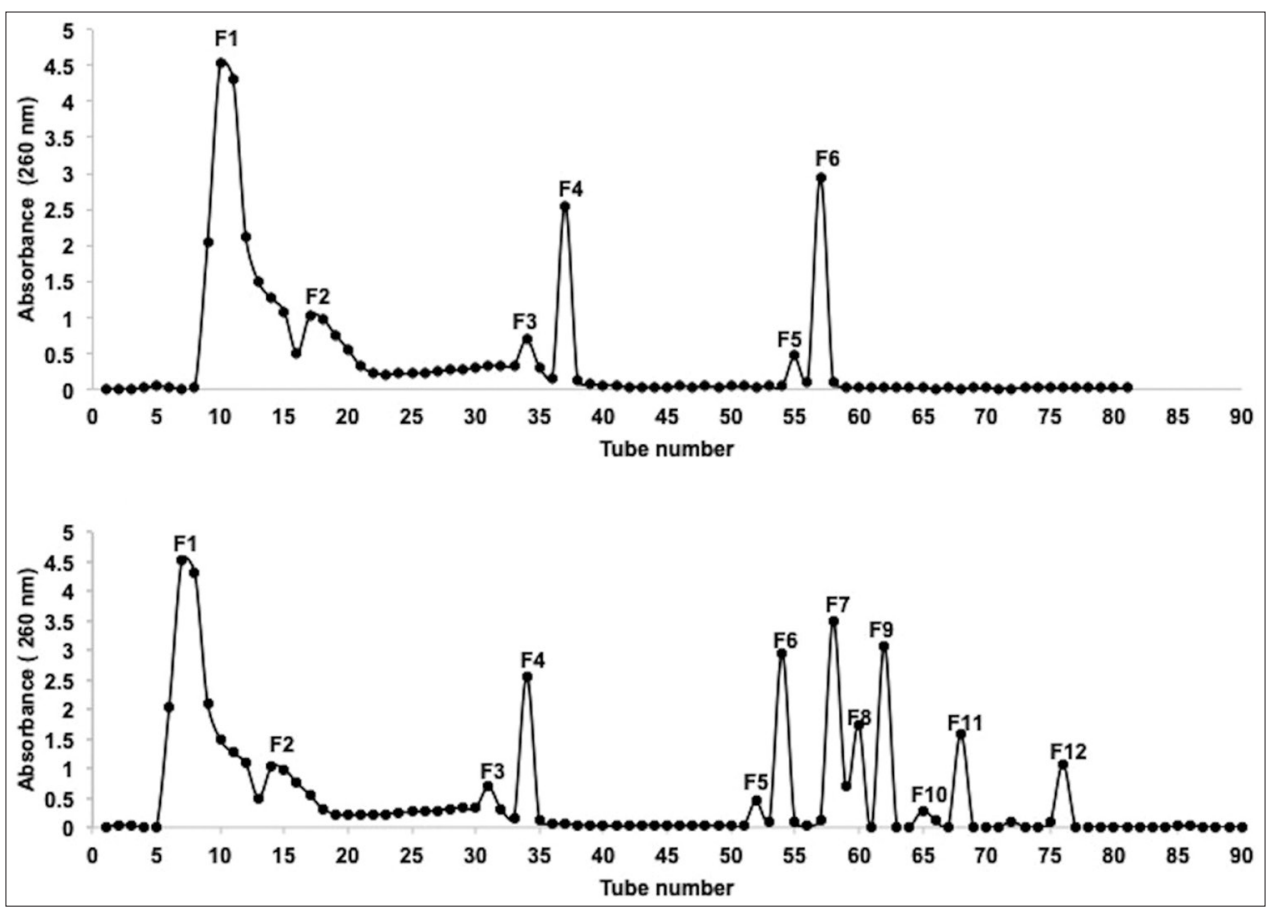

Fig 8. Sephadex G-15 gel chromatography: A) hydrolyzed protein of E. edulis without ultrasonic pretreatment and hydrolysis time of 60 min and $B)$ hydrolyzed protein of $E$. edulis with ultrasonic pretreatment and hydrolysis time of $60 \mathrm{~min}$.

weight bands in legumes suggests that the hydrolysis was extensive, as shown in this investigation, the samples with ultrasonic pretreatment presented the highest ACE inhibitory activity and the lowest molecular weight bands. It is clear that changes in molecular weight of UP samples occurred after ultrasonication by enzymatic hydrolysis. The effect observed in the molecular structure is related to the creation of disturbed flow with high shear, in the liquid environment protein, after ultrasonic pretreatment causing the division of the molecular structure of the protein, helping the availability of some compounds for hydrolysis enzymatic. These results are in agreement with those reported by Jambrak et al. $(2014,2010)$. Nazari et al. (2018) reported changes in the electrophoretic patterns of the protein concentrate of native Panicum miliaceum and treated with ultrasound. It showed important changes in protein fractions, especially in the 40 and $50 \mathrm{kDa}$ links after the treatment in $73.95 \mathrm{~W} / \mathrm{cm}^{2}$ of intensity during $12.5 \mathrm{~min}$.

\section{Gel filtration chomatography}

Gel filtration is known to isolate substances based on their molecular weight (Ji et al., 2014). Fig. 8 shows that in the UP were obtained 12 fractions that were designated as F1 - F12. Showing that fractions F7, F8, F9, F10, F11 and F12 eluted at the end indicate that their molecular weight is smaller compared to other fractions and why they showed a greater inhibitory activity of the ACE, as the results found in this investigation. While in WP only 6 fractions of higher molecular weight are shown. The antioxidant properties of the peptides are more related to their composition, structure and hydrophobicity (Wang et al., 2007), therefore the considerable value of the amino acids like Lys, Met, Trp, Tyr and Phe could be favoured the high antioxidant activity of the hydrolysates. Similarly, amynoacids that have an important role in the inhibitory action of ACE, such as; Pro, Phe, Arg, Trh, Lys and Tyr, that was observed with a high value could be responsible for the coupling to the active site of the ACE (López-Fandiño et al., 2006).

\section{CONCLUSIONS}

The use of pretreatment with ultrasound in the production of bioactive peptides by enzymatic hydrolysis of Erythrina edulis showed that this method helps in the previous breakdown of the protein and thus in the enzymatic hydrolysis. A relationship between the degree of hydrolysis and the in vitro antioxidant activity ABTS* and $\mathrm{DDPH}^{*}$ was observed, showing that the greater the degree of hydrolysis is, the greater the antioxidant activity in vitro. Results of the inhibitory activity of ACE show that the bioactive peptides of Erythrina edulis can be used as an alternative in the processing of nutraceutical products. It will be interesting to examine the behaviour of these peptides in vivo and to perform other biological tests to determine the sequences of these peptides.

\section{ACKNOWLEDGEMENT}

The authors thank the Office of Scientific Research and Development of the University of Tolima for the financial 
support provided for the implementation of this work as well as the GIPRONUT and GIRYSOUT research groups of the University of Tolima. Additionally, the National Technological of Mexico/Technological Institute of Tuxtepec are acknowledged for providing the space for the development of the inter-institutional collaborative work between the two universities.

\section{Authors' contributions}

Carlos Martín Guerra-Almonacid, Juan Gabriel Torruco-Uco and Walter Murillo-Arango conducted the experiments and analyzed the data. Jonh Jairo Méndez-Arteaga and Jesús Rodríguez-Miranda designed the experiments and wrote the manuscript.

\section{Conflict of interest}

None

\section{REFERENCES}

Aderinola, T. A., T. N. Fagbemi, V. N. Enujiugha, A. M. Alashi and R. E. Aluko. 2019. In vitro antihypertensive and antioxidative properties of alcalase derived Moringa oleifera seed globulin hydrolysate and its membrane fractions. J. Food Process. Preserv. 43(2): e13862.

Adler-Nissen, J. 1986. Enzymic Hydrolysis of Food Proteins. Elsevier Applied Science Publishers., London.

Arango-Bedoya, O., V. Bolaños-Patiño, D. Ricaurte-García, M. Caicedo and Y. Guerrero. 2012. Obtención de un extracto proteico a partir de harina de chachafruto (Erythrina edulis). Universidad y . Salud. 14(2): 161-167.

Bae, S. H., and H. J. Suh. 2007. Antioxidant activities of five different mulberry cultivars in Korea. LWT - Food Sci. Technol. 40(6): 955-962.

Betancur-Ancona, D., S. Gallegos-Tintoré and L. Chel-Guerrero. 2004. Wet-fractionation of Phaseolus lunatus seeds: Partial characterization of starch and protein. J. Sci. Food Agric. 84(10): 1193-1201.

Bosiljkov, T., B. Tripalo, M. Brnčić, D. Ježek, S. Karlović and I. Jagušt. 2011. Influence of high intensity ultrasound with different probe diameter on the degree of homogenization (variance) and physical properties of cow milk. Afr. J. Biotechnol. 10(1): 34-41.

Braca, A., C. Sortino, M. Politi, I. Morelli and J. Mendez. 2002. Antioxidant activity of flavonoids from Licania licaniaeflora. J. Ethnopharmacol. 79(3): 379-381.

Cárdenas, S. E. 2012. El Pajuro (Erythrina edulis) alimento andino en extinción. Inv. Sociales. 16(28): 97-104.

Chen, L., J. Chen, J. Ren and M. Zhao. 2011. Effects of ultrasound pretreatment on the enzymatic hydrolysis of soy protein isolates and on the emulsifying properties of hydrolysates. J. Agric. Food Chem. 59(6): 2600--2609.

Chirinos, R., K. Ochoa, A. Aguilar-Galvez, S. Carpentier, R. Pedreschi and D. Campos. 2018. Obtaining of peptides with antioxidant and antihypertensive properties from cañihua protein (Chenopodium pallidicaule Aellen). J. Cereal Sci. 83: 139-146.

Cushman, D. W., and H. S. Cheung. 1971. Spectrophotometric assay and properties of the angiotensin converting enzyme of rabbit lung. Biochem. Pharmacol. 20: 1637--1648.

Ding, Q., T. Zhang, S. Niu, F. Cao, R. A. Wu-Chen, L. Luo and H. Ma. 2018. Impact of ultrasound pretreatment on hydrolysate and digestion products of grape seed protein. Ultrasonund. Sonochem. 42: 704-713.

Guerra, A. C. M., W. Murillo and A. J. J. Méndez. 2017. Antioxidant potential use of bioactive peptides derived from mung bean hydrolysates (Vigna Radiata). Afr. J. Food Sci. 11(3): 67-73.

Gupta, N., and S. S. Bhagyawant. 2018. Angiotensin-I converting enzyme (ACE-I) inhibitory and antiproliferative potential of chickpea seed protein hydrolysate. Ann. Plant Prot. Sci. 7(3): 2149-2153.

Hanafi, M. A., S. N. Hashim, S. Y. Chay, A. Ebrahimpour, M. Zarei, K. Muhammad, A. Abdul-Hamid and N. Saari. 2018. High angiotensin-I converting enzyme (ACE) inhibitory activity of Alcalase-digested green soybean (Glycine max) hydrolysates. Food Res. Int. 106: 589-597.

ljarotimi, O. S., S. A. Malomo, A. M. Alashi, I. D. Nwachukwu, T. N. Fagbemi, O. F. Osundahunsi and R. E. Aluko. 2018. Antioxidant and antihypertensive activities of wonderful cola (Buchholzia coriacea) seed protein and enzymatic protein hydrolysates. J. Food Bioact. 3: 133-143.

Intiquilla, A., K. Jiménez-Aliaga, F. Guzmán, C. A. Alvarez, A. I. Zavaleta, V. Izaguirre and B. Hernández-Ledesma. 2019. Novel antioxidant peptides obtained by alcalase hydrolysis of Erythrina edulis (pajuro) protein. J. Sci. Food Agric. 9(5): 2420-2427.

Intiquilla, A., A. I. Zavaleta and B. Hernández-Ledesma. 2016. Erythrina edulis (Pajuro) seed protein: A new source of antioxidant peptides. Nat. Prod. Commun. 11: 1-6.

Jambrak, A. R., T. J. Mason, V. Lelas and G. Krešić. 2010. Ultrasonic effect on physicochemical and functional properties of a-lactalbumin. LWT-Food Sci. Technol. 43(2): 254-262.

Jambrak, A. R., T. J. Mason, V. Lelas, L. Paniwnyk and Z. Herceg. 2014. Effect of ultrasound treatment on particle size and molecular weight of whey proteins. J. Food Eng. 121: 15-23.

Ji, N., C. Sun, Y. Zhao, L. Xiong and Q. Sun. 2014. Purification and identification of antioxidant peptides from peanut protein isolate hydrolysates using UHR-Q-TOF mass spectrometer. Food Chem. 161: 148-154.

Jia, J., H. Ma, W. Zhao, Z. Wang, W. Tian, L. Luo and R. He. 2010. The use of ultrasound for enzymatic preparation of ACE-inhibitory peptides from wheat germ protein. Food Chem. 119(1): 336-342.

Jiang, Z., K. Yao, X. Yuan, Z. Mu, Z. Gao, J. Hou and L. Jiang. 2018. Effects of ultrasound treatment on physicochemical, functional properties and antioxidant activity of whey protein isolate in the presence of calcium lactate. J. Sci. Food Agric. 98(4): 1522-1529.

Kuskoski, E. M., A. G. Asuero, M. C. García-Parilla, A. M. Troncoso and R. Fett. 2004. Actividad antioxidante de pigmentos antociánicos. Ciênc. Tecnol. Aliment. 24(4): 691-693.

Li, X., S. Da, C. Li, F. Xue and T. Zang. 2018. Effects of high-intensity ultrasound pretreatment with different levels of power output on the antioxidant properties of alcalase hydrolyzates from Quinoa (Chenopodium quinoa Willd.) protein isolate. Cereal Chem. 95(4): 518-526.

Liu, C., L. Fang, W. Min, J. Liu and H. Li. 2018. Exploration of the molecular interactions between angiotensin-l-converting enzyme (ACE) and the inhibitory peptides derived from hazelnut (Corylus heterophylla Fisch.). Food Chem. 245: 471-480.

López-Fandiño, R., J. Otte and J. Van Camp. 2006. Physiological, chemical and technological aspects of milk-protein-derived peptides with antihypertensive and ACE-inhibitory activity. Int. Dairy J. 16(11): 1277-1293.

Ma, S., X. Yang, C. Wang and M. Guo. 2018. Effect of ultrasound treatment on antioxidant activity and structure of $\beta$-Lactoglobulin 
using the Box-Behnken design. CyTA- J. Food. 16(1): 596-606.

Morillo, M., T. Visbal, L. Rial, F. Ovalles, P. Aguirre and A. L. Medina. 2013. Alimentación de alevines de Colossoma macropomum con dietas a base de Erythrina edulis y soya. Interciencia. 38(2): 121-127.

Muguerza, B., M. Ramos, E. Sánchez, M. A. Manso, M. Miguel, A. Aleixandre, M. A. Delgado and I. Recio. 2006. Antihypertensive activity of milk fermented by Enterococcus faecalis strains isolated from raw milk. Int. Dairy J. 16(1): 61-69.

Nadeem, M., N. Ubaid, T. M. Qureshi, M. Munir and A. Mehmood. 2018. Effect of ultrasound and chemical treatment on total phenol, flavonoids and antioxidant properties on carrot-grape juice blend during storage. Ultrasonund. Sonochemistry. 45: 1-6.

Nazari, B., M. A. Mohammadifar, S. Shojaee-Aliabadi, E. Feizollahi and L. Mirmoghtadaie. 2018. Effect of ultrasound treatments on functional properties and structure of millet protein concentrate. Ultrasonund. Sonochem. 41: 382-388.

Pedroche, J., M. M. Yust, J. Girón-Calle, M. Alaiz, F. Millán and J. Vioque. 2002. Utilisation of chickpea protein isolates for production of peptides with angiotensin l-converting enzyme (ACE)-inhibitory activity. J. Sci. Food Agric. 82(9): 960-965.

Rahmaninia, M., M. Rohi, M. A. Hubbe, S. M. Zabihzadeh and O. Ramezani. 2018. The performance of chitosan with bentonite microparticles as wet-end additive system for paper reinforcement. Carbohydr. Polym. 179: 328-332.

Ren, X., H. Ma, S. Mao and H. Zhou. 2014. Effects of sweeping frequency ultrasound treatment on enzymatic preparations of ACE-inhibitory peptides from zein. Eur. Food Res. Technol. 238(3): 435-442.

Resendiz-Vazquez, J. A., J. A. Ulloa, J. E. Urías-Silvas, P. U. Bautista-Rosales, J. C Ramírez-Ramírez, P. Rosas-Ulloa and L. González-Torres. 2017. Effect of high-intensity ultrasound on the technofunctional properties and structure of jackfruit (Artocarpus heterophyllus) seed protein isolate. Ultrasonund. Sonochem. 37: 436-444.

Sambrook, J., E. F. Fritsch and T. Maniatis. 1989. Molecular Cloning: A Laboratory Manual (No. Ed. 2). Cold Spring Harbor Laboratory Press., Harbor.

Sarmadi, B. H., and A. Ismail. 2010. Antioxidative peptides from food proteins: A review. Peptides. 31: 1949-1956.

Schaich, K. M., X. Tian and J. Xie. 2015. Hurdles and pitfalls in measuring antioxidant efficacy: A critical evaluation of ABTS,
DPPH, and ORAC assays. J. Func. Foods. 14: 111-125.

Torruco-Uco, J., L. Chel-Guerrero, A. Martínez-Ayala, G. Dávila-Ortíz and D. Betancur-Ancona. 2009. Angiotensin-I converting enzyme inhibitory and antioxidant activities of protein hydrolysates from Phaseolus lunatus and Phaseolus vulgaris seeds. J. Food Sci. Technol. 42: 1597-1604.

Tsai, J. S., J. L. Chen and B. S. Pan. 2008. ACE-inhibitory peptides identified from the muscle protein hydrolysate of hard clam (Meretrix lusoria). Process Biochem. 43: 743--747.

Udenigwe, C. C., R. E. Aluko. 2012. Food protein-derived bioactive peptides: Production, processing, and potential health benefits. J. Food Sci. 77(1): R11-R24.

Wang, B., G. G. Atungulu, R. Khir, J. Geng, H. Ma, Y. Li and B. Wu. 2015. Ultrasonic treatment effect on enzymolysis kinetics and activities of ACE-inhibitory peptides from oat-isolated protein. Food Biophys. 10(3): 244-252.

Wang, J. S., M. M. Zhao, Q. Z. Zhao and Y. M. Jiang. 2007. Antioxidant properties of papain hydrolysates of wheat gluten in different oxidation systems. Food Chem. 101(4): 1658-1663.

Xiong, T., W. Xiong, M. Ge, J. Xia, B. Li and Y. Chen. 2018. Effect of high intensity ultrasound on structure and foaming properties of pea protein isolate. Food Res. Int. 109: 260-267.

Yang, B., H. Yang, J. Li, Z. Li and Y. Jiang. 2011. Amino acid composition, molecular weight distribution and antioxidant activity of protein hydrolysates of soy sauce lees. Food Chem. 124(2): 551-555.

Yang, B., M. M. Zhao, J. Shi, N. Yang and Y. M. Jiang. 2008. Effect of ultrasonic treatment on the recovery and DPPH radical scavenging activity of polysaccharides from longan fruit pericarp. Food Chem. 106: 685-690.

You, L., M. Zhao, C. Cui, H. Zhao and B. Yang. 2009. Effect of degree of hydrolysis on the antioxidant activity of loach (Misgurnus anguillicaudatus) protein hydrolysates. Innov. Food Sci. Emerg. Technol. 10(2): 235-240.

Zhang, Y., H. Ma, B. Wang, W. Qu, Y. Li, R. He and A. Wali. 2015. Effects of ultrasound pretreatment on the enzymolysis and structural characterization of wheat gluten. Food Biophys. 10(4): 385-395.

Zhang, Y., L. Ma, L. Cai, Y. Liu and J. Li. 2017. Effect of combined ultrasonic and alkali pretreatment on enzymatic preparation of angiotensin converting enzyme (ACE) inhibitory peptides from native collagenous materials. Ultrasonund. Sonochem. 36: 88-94. 